\title{
A Holocene pollen record of savanna establishment in coastal Amapá
}

\author{
MAURO B. DE TOLEDO ${ }^{1}$ and MARK B. BUSH ${ }^{2}$ \\ ${ }^{1}$ Departamento de Geologia, Universidade Federal Fluminense (UFF), Av. Gal. Milton Tavares de Souza s/n, \\ $4^{\circ}$ andar, Gragoatá, 24210-340 Niterói, RJ, Brasil \\ ${ }^{2}$ Department of Biological Sciences, Florida Institute of Technology, 150 W. University Blvd., Melbourne, Florida 32901, USA \\ Manuscript received on September 6, 2006; accepted for publication on May 25, 2007; \\ presented by ALCIDES N. SIAL
}

\begin{abstract}
The main goal of this study was to investigate how climate and human activities may have influenced ecotonal areas of disjoint savannas within Brazilian Amazonia. The fossil pollen and charcoal records of Lake Márcio (Amapá) were used to provide a Holocene palaeoecological history of this region. Detrended correspondence analysis (DCA) was used to enhance the patterns of sample distribution along the sediment core. A marked vegetation change from closed forests with swamp elements to open flooded savanna at c. $5000 \mathrm{yrs}$ BP was evident from the pollen record. Charcoal analysis revealed a pattern of increased accumulation of particles coincident with the establishment of savannas, suggesting higher fire frequency and human impacts near the lake. A 550-year sedimentary hiatus suggests that the lake depended heavily on floodwaters from the Amazon River, and that it became suddenly isolated from it. When sedimentation restarted in the lake, the environment had changed. A combination of factors, such as reduced river flooding, palaeofires and human occupation may have had a tremendous impact on the environment. As there are no other major changes in vegetation, after $4700 \mathrm{yrs} \mathrm{BP}$, it is plausible to assume that the modern mosaic vegetation formed at that time.
\end{abstract}

Key words: pollen record, palaeofires, Amazonia, savannas, climate change, palaeoecology.

\section{INTRODUCTION}

Even though the core area of savannas is in central Brazil, disjunct savannas are present in the Brazilian Amazonia (e.g. Amapá, Marajó Island, Alter do Chão, and Roraima) (Salgado-Labouriau 1997). However, the largest continuous area (c. $40,000 \mathrm{~km}^{2}$ ) of natural savannas within the Brazilian Amazonia is located in Roraima (Miranda and Absy 1997, Silva 1997).

Over the last 20 years, the early view of an Amazonia pristine and untouched has changed. Archeological studies provided evidence that humans have lived in Amazonian lowlands for at least 11,000 years (Roosevelt et al. 1991, 1996). Further evidence that these landscapes have been intensely used and modified by pre-Columbian human populations comes from savan-

Correspondence to: Mauro B. de Toledo

E-mail: mtoledo@igeo.uff.br nas in the Bolivian Amazonia and Upper Xingu (Erickson 2000, 2001, Heckenberger et al. 2003). However, the full extent of the Pre-European manipulation of Amazonian habitats remains unclear (Meggers 2003).

Although human activities are known to have altered Amazonian environments, Holocene climatic changes have also been invoked to account for variation in the range of savannas. A palaeoecological study conducted on a landscape of forest-savanna ecotone in Bolivia revealed a forest expansion of c. $100 \mathrm{~km}$ in the last 3000 years (Mayle et al. 2000). Similarly, palaeoecological records from Colombian savannas also suggest a forest expansion in the last 4000 years (Behling and Hooghiemstra 1998, 1999, Berrio et al. 2002).

Associated either with human activity or climatic change, fires can be an important element in shaping the environment and vegetation of a region (Cochrane 
and Schulze 1999), and in determining the community structure of some ecosystems. As fire frequency is at least partially climatically controlled, charcoal analyses of sediments that quantify palaeofires may provide a proxy for past climate changes (Patterson et al. 1987, Clark 1988, Behling 1996, Clark et al. 1996, Kennedy and Horn 1997, Bush et al. 2000). Although it can also indicate anthropogenic activities, as humans have used fire to modify landscapes throughout human history.

Because the size of charcoal particles may indicate the distance from the fires to the study site, charcoal particles in lake sediments can provide information about fire frequency on a small or large geographic scale (local or regional fires respectively). Small particles can be transported further than larger particles, and therefore represent regional fires. Whereas large particles of charcoal reflect fires that burned near the site.

\section{STUDY SiTE}

Lake Márcio (c. $0{ }^{\circ} 07^{\prime} 40.9^{\prime \prime} \mathrm{N} 51^{\circ} 04^{\prime} 47.8 " \mathrm{~W}$ ) is $10 \mathrm{~km}$ from the Amazon River. The lake is $1.5-2.5 \mathrm{~m}$ deep, and lies at less than $10 \mathrm{~m}$ above sea level (Fig. 1), being part of a much larger hydrologic system known as Curiaú. Lake Curiaú is an L-shaped basin $6.5 \mathrm{~km}$ long in the vertical axis, $3.5 \mathrm{~km}$ long in the horizontal axis, and $1.2 \mathrm{~km}$ wide; its watershed is estimated to be at least $150 \mathrm{~km}^{2}$. Lake Márcio occupies an area of about $300 \times 350 \mathrm{~m}$ on the northern tip of Lake Curiaú, and although Curiaú may dry out almost completely in the dry season, Márcio is known as a permanent water body.

The studied lake is located in an area presently occupied by small settlements that form a community founded by former slaves who escaped and built a village during the XVIII century. About 1500 people, all descendants of the former slaves live today in the village.

The vegetation of the study site is a mosaic of dry and flooded savannas and patches of secondary and dry forests. Gallery forests and palm swamps are also present along the water drainages (igarapés). Lake Márcio is surrounded by savanna vegetation, with a fringe of Mauritia palms on the shoreline. In a phytosociological study in this region, Thomaz et al. (2004) identified 44 families, 83 genera and 119 species. The most important families were Cyperaceae (18 species), Poaceae (15 species), Fabaceae (7 species), Rubiaceae (3 species), Lentibula-

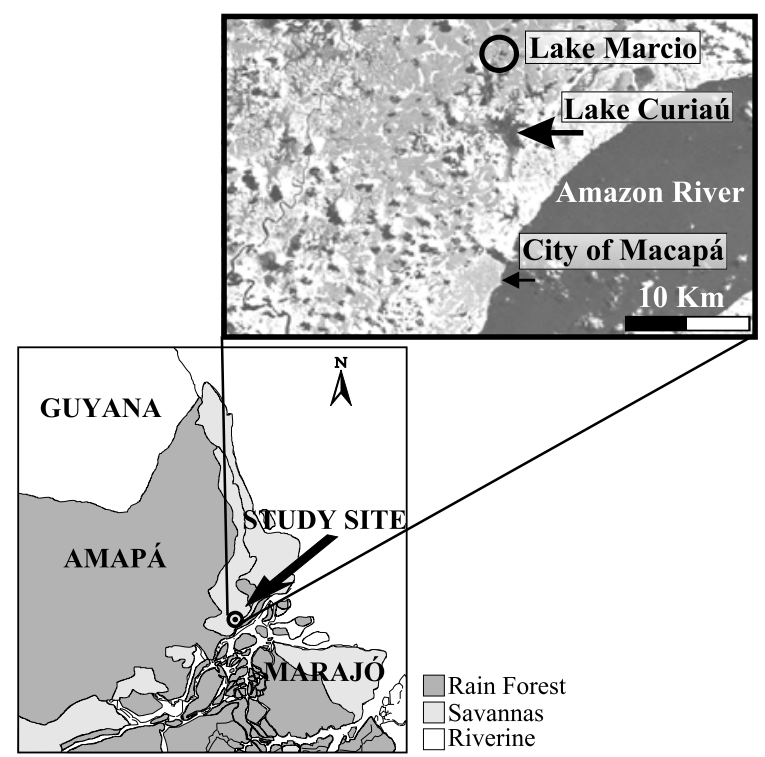

Fig. 1 - Map of the study area, showing the location of Lakes Curiaú and Márcio (the study lake), the City of Macapá, and the Amazon River.

riaceae and Onagraceae ( 5 species each). It is noteworthy to mention that among the dominant species were Sagittaria rhombifolia, Montrichardia arborescens and Mauritia flexuosa, and the latter ones are found in isolated populations throughout the Curiaú watershed.

The climate in this region is tropical humid, with mean annual temperatures of $25-27^{\circ} \mathrm{C}$ and $2500 \mathrm{~mm}$ of precipitation, falling mainly between December-August with a dry season from September to November (IBGE 2002).

\section{MATERIALS AND METHODS}

The sediment core was raised from the middle of the lake using a Colinvaux-Vohnout piston corer (Colinvaux et al. 1999). The sealed core tubes were transported unopened to the laboratory and stored in a dark cold room until opened and the sediments described. Twenty-nine samples $\left(0.5 \mathrm{~cm}^{3}\right)$ for pollen and 39 for charcoal were collected from the sediment core. The $\mathrm{C}^{14}$ (AMS) samples were dated at the INSTAAR (University of Colorado at Boulder), and the ages were calibrated using CALIB 4.0 (Stuiver and Reimer 1993).

Standard pollen extraction procedures with $\mathrm{HCl}$, $\mathrm{KOH}, \mathrm{HF}$, and acetolysis followed (Faegri and Iversen 1989) and (Stockmarr 1971) for the addition of tablets 
of Lycopodium spores to calculate pollen concentrations. At least 300 grains of terrestrial taxa were counted for each sample. Pollen grains were identified using the Florida Tech reference collection and published pollen catalogs (Hooghiemstra 1984, Roubik and Moreno 1991, Colinvaux et al. 1999). The pollen sum (only terrestrial taxa), percentage and concentration were calculated in TILIA (Grimm 1992). The diagrams were plotted in $C^{2}$ 1.4 (Juggins 2003).

Samples for charcoal analysis were processed with $\mathrm{KOH}(10 \%)$ and sieved through a $170 \mu \mathrm{m}$ mesh (keeping particles $>170 \mu \mathrm{m})$. The charcoal analysis was conducted under an Olympus dissection microscope $(20 \times$ magnification) equipped with a video camera (Clark and Patterson 1997). Charcoal particles were digitally measured using image recognition software (NIH-IMAGE), which provides the area of particles $\left(\mathrm{mm}^{2}\right)$ according to the number of pixels occupied by the fragment on the screen.

Detrended Correspondence Analysis - DCA (Hill and Gauch 1980) was performed using PC-ORD 4.0 (McCune and Mefford 1999). This technique was chosen because it is not subject to the infamous arch effect, and the axes can be rescaled to estimate the degree of species turnover. The matrix included only taxa with percentage values equal to or higher than $1 \%$ and present in at least 3 samples throughout the core, and was standardized by square root transformation (McCune and Grace 2002). Because the eigenvalues provided by DCA cannot be used to demonstrate the proportion of variation, we used an after-the-fact coefficient of determination (McCune and Grace 2002) in order to evaluate the effectiveness of the ordination. The sample scores from axis 1 were plotted against sample depths.

\section{RESULTS}

\section{STRATIGRAPHY}

The $470 \mathrm{~cm}$-long sediment core from Lake Márcio (Fig. 2) shows a strong change in sediment type at $118 \mathrm{~cm}$. Below $118 \mathrm{~cm}$ the core is composed of bluegrey clay with wood and charcoal fragments, while above $118 \mathrm{~cm}$ sediments are composed of gyttja rich in plant remains (Table I). The core pierced and passed through a $\log$ of wood, $38 \mathrm{~cm}$ in width that forms the section of core from $347-385 \mathrm{~cm}$.
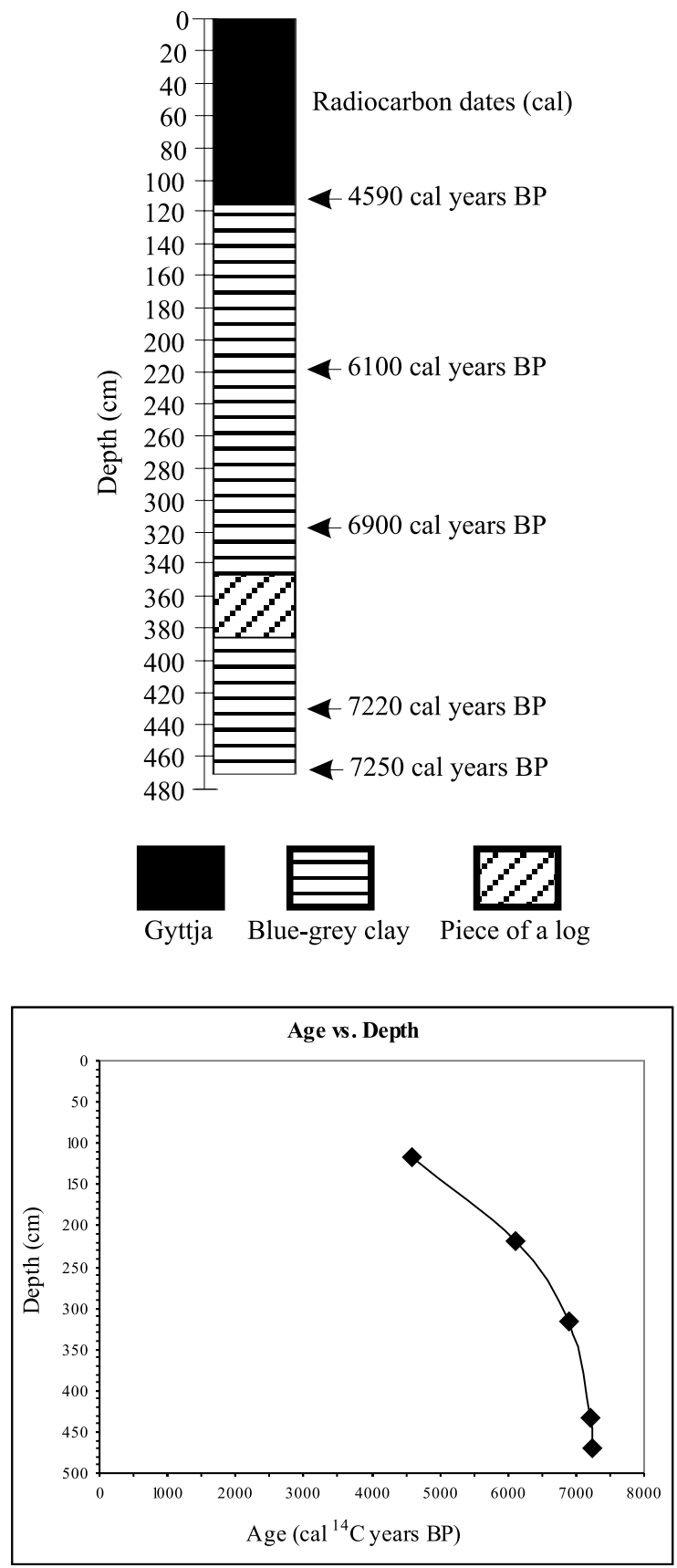

Fig. 2-Lithology of sediment core from Lake Márcio, Amapá (Brazil). Also showing location of dated samples in cal yrs BP (top). Radiocarbon ages from Lake Márcio plotted against depth (cm) (bottom).

\section{RADIOCARBON DATES}

Chronology for Lake Márcio was derived from five AMS dates (Table II). All ages used henceforth will be inter- 
TABLE I

Sediment description of core from Lake Márcio (Amapá - Brazil).

\begin{tabular}{c|l}
\hline Depth $(\mathrm{cm})$ & Sediment description \\
\hline $0-118$ & Gyttja - black peaty mud, very organic rich in plant remains \\
\hline $118-347$ & $\begin{array}{l}\text { Blue-gray clay, with wood and charcoal fragments at } \\
\text { different concentrations throughout the core }\end{array}$ \\
\hline $347-385$ & Piece of a log that was cored through longitudinally \\
\hline $385-470$ & Gray clay with pieces of charcoal \\
\hline
\end{tabular}

TABLE II

Radiocarbon dates from Lake Márcio.

\begin{tabular}{c|c|c|c|c}
\hline Sample & Depth $(\mathrm{cm})$ & ${ }^{14} \mathrm{C}$ yr BP & ${ }^{13} \mathrm{C} /{ }^{12} \mathrm{C}$ ratio & Age (cal years BP) \\
\hline OS-24117 & 116 & $4100 \pm 35$ & -27.30 & $4520-4660$ \\
\hline OS-24118 & 218 & $5330 \pm 45$ & -25.60 & $5990-6210$ \\
\hline OS-24119 & 317 & $6050 \pm 40$ & -29.30 & $6790-7000$ \\
\hline OS-24120 & 432 & $6280 \pm 40$ & -27.30 & $7160-7280$ \\
\hline OS-24121 & 470 & $6320 \pm 45$ & -27.80 & $7160-7330$ \\
\hline
\end{tabular}

polated calibrated years (cal. yrs) before present (BP), unless noted otherwise. The basal age of $7250 \mathrm{cal}$. yrs BP for Lake Márcio indicates that the sediments provide a Holocene history. The $38 \mathrm{~cm}$ width of the log penetrated in Márcio is taken to represent instant deposition and so was removed from the calculations of sedimentation rates. The age vs. depth relationship (Fig. 2) shows that sedimentation rates were not constant through time, being fast in the basal portion of the core, and slowing up core (Fig. 2).

\section{Palaeoecological Record}

The pollen and charcoal records (Fig. 3) allow the distinction of two main zones: zone M1 (from c. $7250 \mathrm{cal}$. yr BP until 4590 cal. yr BP), being subdivided into zones M1A, M1B, and M1C; and zone M2 (from c. 4,590 cal. yr BP until the present). The diagram zonation was based on DCA results and visual inspection.

\section{M1A $(470 \mathrm{~cm}-320 \mathrm{~cm} ; \mathrm{c} .7250$ to c. 6910 yrs BP)}

Sediments are composed of blue-grey clay with wood and charcoal fragments. Pollen concentration increases from c. 50,000 to c. 170,000 grains $\mathrm{cm}^{-3}$ of sediment upwards (Fig. 3). The pollen spectra are characterized by the presence of Alseis and Apeiba (not shown in the diagram) at low percentages; this is the only zone in which these 2 genera were found. Arecaceae and Rhizophora show their highest values in this zone. Apocynaceae, Araliaceae, Asteraceae, Astronium, Bignoniaceae, Cassia, Cupania, Cecropia, Dalbergia, Malpighiaceae, Mauritia, Poaceae, Protium, Symphonia, and Virola are present with low percentages. Papillionaceae occurs at $3-5 \%$ in this zone. Pollen from Andean taxa, such as Alnus, Iriartea, and Podocarpus are present with low percentages. The amount of charcoal particles present is negligible (c. $0.5 \mathrm{~mm}^{2} \mathrm{~cm}^{-3}$ of sediment).

\section{M1B $(320 \mathrm{~cm}-200 \mathrm{~cm} ; \mathrm{c.} 6910$ to 5840 yrs BP)}

Sediments are composed of blue-grey clay with wood and charcoal fragments. Pollen concentration decreases from c. 150,000 to c. $50,000-80,000$ grains $\mathrm{cm}^{-3}$ of sediment upwards (Fig. 3). The pollen spectra are characterized by low percentages of Alchornea and Poaceae. Pollen of Apocynaceae, Araliaceae, Arecaceae, Asteraceae, Cupania, Dalbergia, Papillionaceae and Rhizopho$r a$ all decline in abundance. Conversely, pollen from Astronium, Bignoniaceae, Cassia, Cecropia, Euterpe, Malpighiaceae, Protium, Symphonia, and Virola show increased percentages in this zone. Pollen from swamp/ aquatic plants such as Cyperaceae, Sagittaria and Typha start being deposited. Podocarpus (with slightly higher percentage values) and pollen of the western Amazonian 


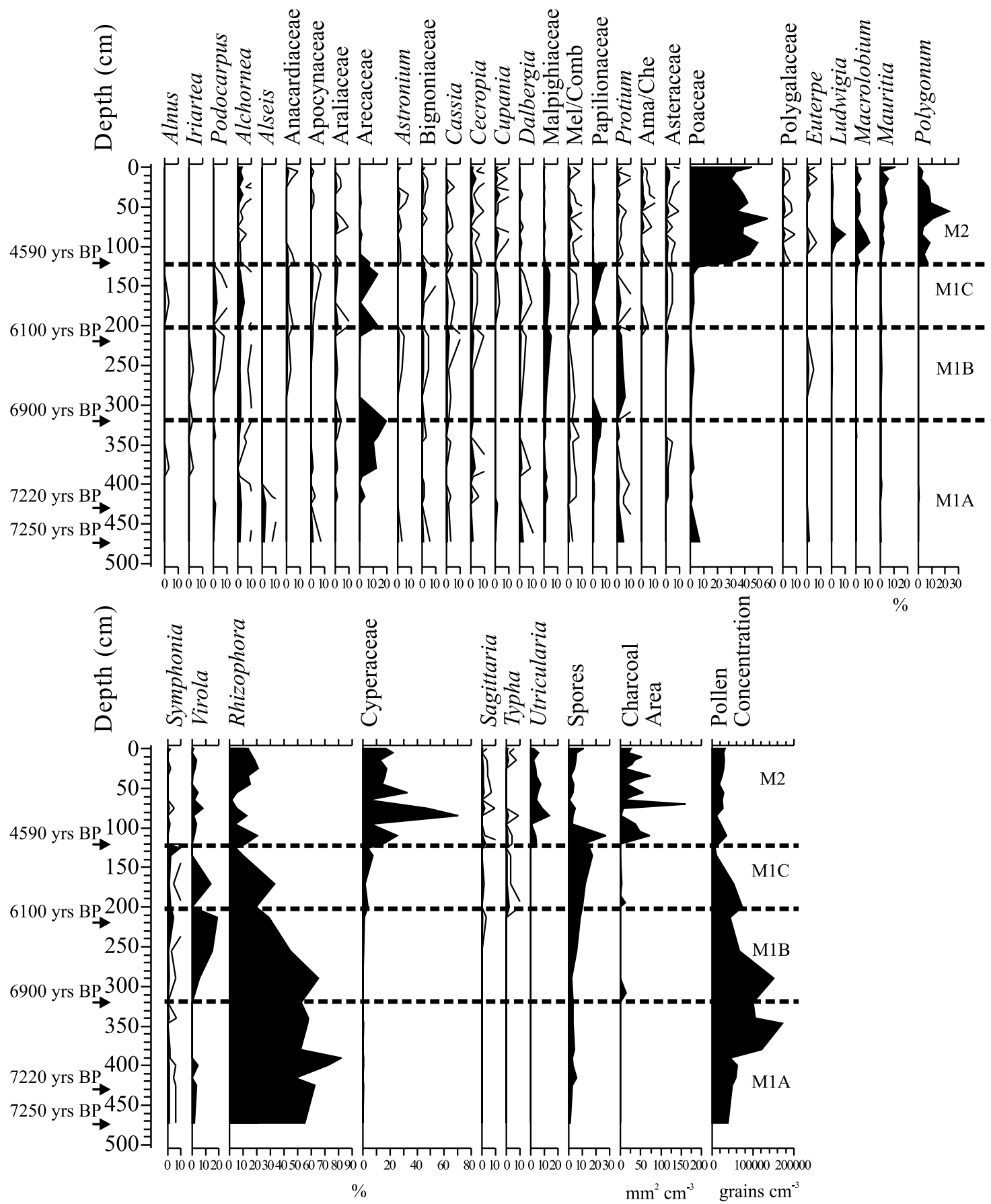

Fig. 3 - Pollen percentage diagram of Lake Márcio, Amapá (Brazil), showing the most representative taxa, including Andean taxa, area of charcoal particles ( $\mathrm{mm}^{2} \mathrm{~cm}^{-3}$ of sediment), pollen concentration (grains $\mathrm{cm}^{-3}$ of sediment), and radiocarbon dates (cal years BP). The hollow curves are exaggerated 5 times. 
palm Iriartea are also recorded in this zone. A peak in the accumulation of charcoal particles (c. $16 \mathrm{~mm}^{2} \mathrm{~cm}^{-3}$ of sediment) occurs at the beginning of this zone.

$\operatorname{MIC}(200 \mathrm{~cm}-120 \mathrm{~cm} ; \mathrm{c} .5840$ to $4750 \mathrm{yrs} \mathrm{BP})$

Sediments are composed of blue-grey clay with wood and charcoal fragments. Pollen concentration decreases from c. 80,000 to c. 15,000 grains $\mathrm{cm}^{-3}$ of sediment upwards (Fig. 3). The pollen spectra are characterized by increased percentages of Alchornea, Apocynaceae, Araliaceae, Arecaceae, Asteraceae, Bignoniaceae, Dalbergia, Papillionaceae, Melastomataceae/Combretaceae type (Mel/Comb), and Podocarpus. Poaceae pollen has a 7-fold increase in abundance (c. 5-35\%) in the top part of this zone. Cassia, Cecropia, Malpighiaceae, Protium, Virola and Rhizophora show slightly decreased percentages. Pollen from Amaranthus/Chenopodiaceae type (Ama/Che) is recorded for the first time, but still at low values. Pollen grains from Andean taxa such as $\mathrm{Al}$ nus and Podocarpus are recorded at this zone, although pollen from Iriartea is absent. Another peak in the accumulation of charcoal particles (c. $13 \mathrm{~mm}^{2} \mathrm{~cm}^{-3}$ of sediment) is found in the beginning of this zone.

\section{M2 (120 cm-0 cm; c. 4750-4650 yrs BP to present)}

Sediments are composed of gyttja rich in plant remains. Pollen concentration fluctuates around c. 30,000 grains $\mathrm{cm}^{-3}$ of sediment (Fig. 3). Pollen spectra are characterized by relatively low percentages of Alchornea, Apocynaceae, Arecaceae, Bignoniaceae, Cassia, Dalbergia, Papillionaceae, Malpighiaceae, Protium, Symphonia, Virola, and Rhizophora. Pollen from Alnus, Iriartea, and Podocarpus are absent from this zone. Ludwigia, Macrolobium, Polygalaceae, Polygonum, and Utricularia are recorded only in this top zone with percentage values varying from 2-3\% (Polygalaceae) to $20 \%$ (Polygonum). Amaranthus/Chenopodiaceae pollen shows slightly higher percentage values. Percentage of Poaceae pollen displays some fluctuation, but remains high until the end of the zone. Accumulation of charcoal particles is greatly increased in this zone. There are at least 5 peaks of charcoal varying in area from $50-140 \mathrm{~mm}^{2} \mathrm{~cm}^{-3}$ of sediment.

\section{Multivariate ANALYsis}

The resulting DCA scores were plotted in two different ways. First, axis 1 vs. axis 2, then the sample scores from axis 1 were plotted against the corresponding depths (Fig. 4). The proportion of variance explained by the first two axes, as given by the after-the-fact coefficient of determination, was $88 \%$.

\section{Axis 1 vs. Axis 2}

The DCA scores from axes 1 and 2 (Fig. 4) showed a strong polarization of samples on axis 1 that divided them into two main groups: the bottom samples of the core on the right and the top samples of the core on the left representing zones M1 (ABC) and M2 (respectively). The species that scored highest and therefore were the most characteristic of samples being placed on the positive side of axis 1 were Alseis, Podocarpus, Rhizophora, Symphonia, and Arecaceae. The lowest scores were yielded by Polygala, Utricularia, Polygonum, Ludwigia, and Macrolobium, which brought the samples to the negative side of axis 1 in zone M2. A relatively weaker polarization of samples that corresponded to zones M1A and M1C was also observed on axis 1. Axis 2 displayed a very weak polarization of samples into groups subdividing zone M1, therefore only axis 1 was plotted against depth.

\section{Axis 1 vs. Depth}

The contrast in the DCA scores between the samples in groups M1 (ABC) and M2 was especially pronounced when plotted against depth (Fig. 4). Within their respective groups the samples showed little variation, however the transition from zone M1 (ABC) to zone M2 is seen to occur abruptly at $120 \mathrm{~cm}$ (between c. $6100 \mathrm{cal}$. yr BP and 4590 cal. yr BP).

\section{DISCUSSION}

Stratigraphy alone indicates that Lake Márcio provides a record of an environmental change, as the core showed blue-grey clay being replaced by black-organic sediments (Fig. 2). The sharp transition of the sediments implied that this change was at least locally profound and maybe even abrupt. The blue-grey clay that constituted the bottom of the sediment core was full of plant remains, 


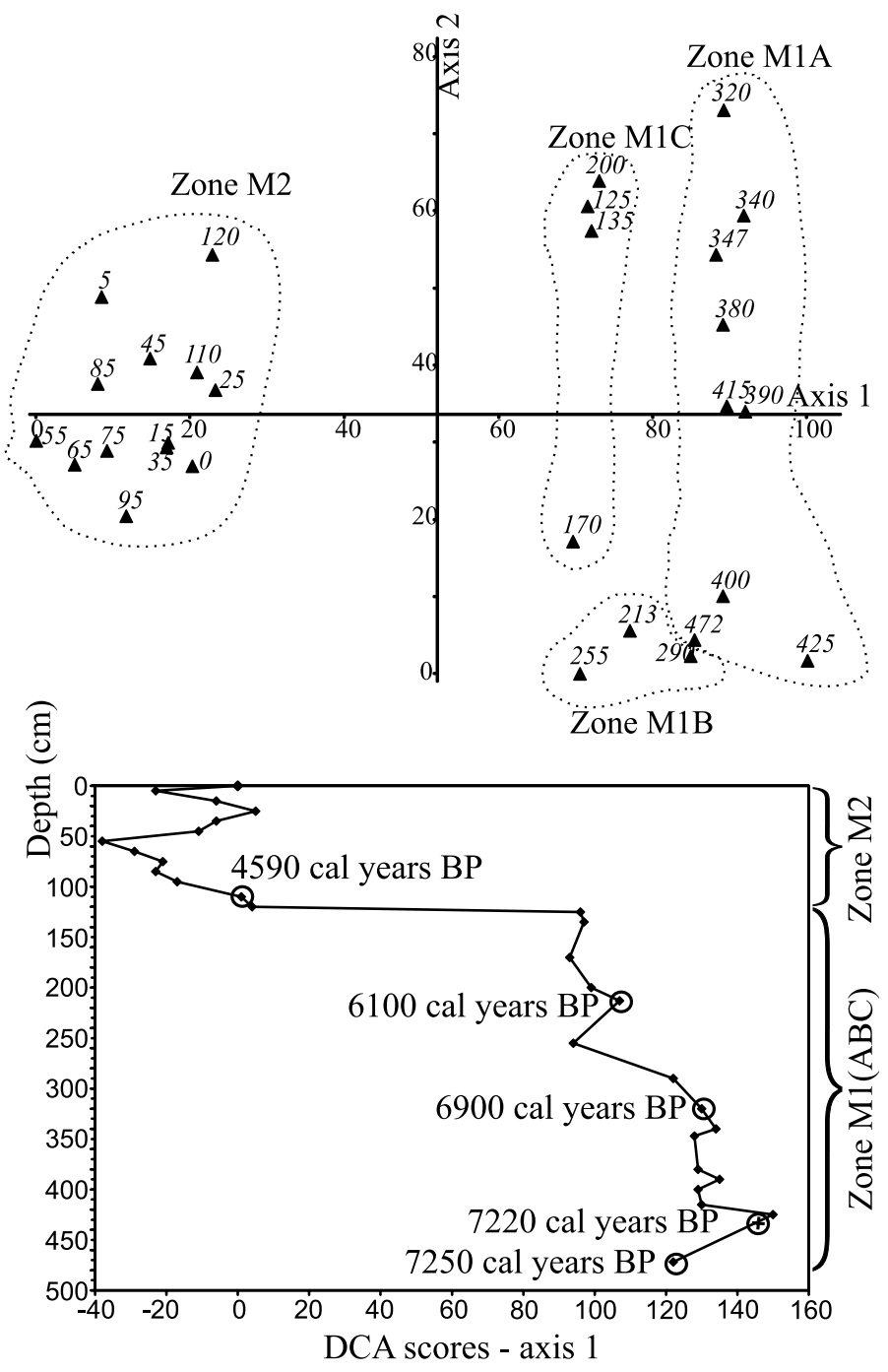

Fig. 4 - DCA scores from Lake Márcio. Top graph shows axis 1 vs. axis 2. Samples are grouped according to zones interpreted from pollen diagrams. Bottom graph displays resulting DCA scores of axis 1 plotted $v s$. depth $(\mathrm{cm})$ showing a strong polarization of samples into two main groups representing zones M1 (ABC) and M2.

wood and fragments of charred wood, indicating a shallow and unstable depositional environment. The coring location may have supported a gallery forest subjected to periodic river flooding, which may explain the presence of wood and plant fragments, especially the log that was pierced during coring.

The sedimentation rates provided further evidence of an alteration in the environment (Fig. 2). The clays of zone M1 had an average sedimentation rate of $\sim 0.13 \mathrm{~cm} \mathrm{yr}^{-1}$, but sedimentation in the upper $116 \mathrm{~cm}$ of the core was at just $0.03 \mathrm{~cm} \mathrm{yr}^{-1}$, a five-fold decrease. The obvious slowing coincided with the transition from a core dominated by allochthonous clays to autochthonous organic material.

A sharp break in sediment type, a rapid change in community composition, and different sediment deposition rates above and below the boundary suggest the possible presence of a sedimentary hiatus in the lake. 
Given the above, a simple projection of sedimentation rates above and below the sediment boundary to the point of the transition at $118 \mathrm{~cm}$ revealed a temporal mismatch in the sediment core (i.e. an apparent gap). Applying the sedimentation rate of $0.123 \mathrm{~cm} \mathrm{yr}^{-1}(317-218 \mathrm{~cm})$, the interpolated age for the clay at $120 \mathrm{~cm}$ (immediately beneath the transition) would be $5300 \mathrm{cal}$. yrs BP. Similarly, by projecting the sedimentation rate for the sediments between $0-116 \mathrm{~cm}$ downward, an interpolated age for onset of the organic sediment deposition at $120 \mathrm{~cm}$ would be 4750 cal. yrs BP. A possible explanation of all the observed sedimentary and biological changes is a 550-year gap in sedimentation $(5300-4750=550)$. Such breaks in sedimentation are common in shallow tropical lakes (Listopad 2001) and are generally taken to indicate conditions in which lake level fell.

The timing of this event is consistent with the most significant change in sediment and pollen inputs to an 11,000-year record from Lago Tapajós (Irion et al. 2006) that took place between 5500 and 4200 yrs BP. In that record, increased abundance of Poaceae pollen and a shift to finer sediments is inferred to represent a combined human and climatically-induced expansion of open habitats and reduced river discharge.

The pollen and charcoal records from Lake Márcio revealed two main contrasting zones. The most obvious biological distinction between these zones was the increase in Poaceae pollen, rising from $<10 \%$ in M1 to almost 60\% (30-55\%) in M2. These percentage values are comparable with the proportion of Poaceae pollen $(50-90 \%)$ that is found in the pollen rain of cerrados (Salgado-Labouriau 1973), suggesting the establishment of the savanna vegetation.

Even though comparable percentages of Poaceae pollen are also observed in records from Colombian savannas such as Lagunas Carimagua and El Piñal (Behling and Hooghiemstra 1999), Lagunas Chenevo and Mozambique (Berrio et al. 2002), and Lagunas Angel and Sardinas (Behling and Hooghiemstra 1998), an increase in Poaceae, as marked as the one observed in Lake Márcio could be found only in the Lake Crispim (northern coast of Pará) pollen record (Behling and Costa 2001).

A further indication of a significant vegetation change was the loss of Rhizophora pollen in zone M2. After c. 7000 cal. yr BP the declining proportion of
Rhizophora pollen suggests a weakening of the marine influence, possibly as the Curiaú hydrologic system became more isolated from the Amazon channel. Replacement of forest taxa, e.g. Alseis, Apocynaceae, Bignoniaceae, Cassia, Malpighiaceae, Papillionaceae, Podocarpus, Protium, Symphonia, and Virola (Marchant et al. 2002) in M2 with those from flooded savanna and swamp vegetation, such as Amaranthus/Chenopodiaceae, Asteraceae, Ludwigia, Macrolobium, Mauritia, Polygonum, Cyperaceae, and Utricularia, is consistent with a shift toward less dense forest. Significantly, some swamp indicator taxa such as Ludwigia, Macrolobium, and Polygonum were present only in $\mathrm{M} 2$, reinforcing the suggestion of a general trend towards flooded savanna vegetation.

The sample scores derived from DCA when plotted with core depths provided an illustrative way to demonstrate the impact of environmental changes that took place in that system. The axis 1 demonstrated the same general pattern, and was interpreted to show a hydrology gradient, changing from an environment subjected to seasonal river flooding, to a more isolated one. The landscape changed from a gallery forest type to a swamp forest with strong influence of savanna. The timing of the environmental change was coincident with the on set of fires around the lake. The replacement of Symphonia and Virola in M1 by Macrolobium, Mauritia, e Polygonum in M2 suggested subtle changes within the community of wetland plants.

To sum up, a general environmental trend from gallery forest (M1) to a savanna with swamp elements (M2) was apparent. Anthropogenic impacts on the environment were suggested by extremely large quantities of charcoal particles especially after c. 4590 cal. yr BP.

\section{The Vegetation Change}

When sedimentation at Márcio resumes at c. 4700 cal. yr BP, the pollen signal is very different to that prior to the hiatus. The reduction in wet forest taxa and the abundance of open ground indicators, coupled with the consistent presence of large quantities of charcoal lead us to infer that fire was maintaining these areas of savanna.

A combination of factors may have contributed to this change. A change in the flood regimes probably amplified the effects of lake isolation, which may have 
caused the system to shift from allochthonous to autochthonous deposition. The locally drier conditions at c. 5200 cal. yr BP may have also encouraged human expansion into this setting. The precise pattern of events remains to be resolved, but the effect was that by 4700 yr BP land adjacent to Márcio supported an extensive savanna/swamp and a landscape subject to regular burning rather than wet forest. As there is no evidence of changes in lake status, and that no significant change in pollen composition has taken place in the last 4700 years, it is parsimonious to assume that the modern lake and savannas formed at this time.

\section{Comparable Pollen Records}

The fossil pollen records from Amazonia that present the most similar vegetation change are located relatively near Amapá (Guyana, French Guyana, Suriname, and Pará State). Even though all these records show the same overall pattern of vegetation change with a similar timing (i.e. forests and mangroves being replaced by savannas), the interpretation of each record was slightly different. While the vegetation changes inferred from a sediment core from French Guyana were interpreted to be the result of a coastal progradation due to sea-level changes (Tissot et al. 1987), the records from Guyana (van der Hammen 1963), Suriname (Wijmstra 1971), and coastal Pará (Behling and Costa 2001), were simply attributed to sea-level fall, which would produce a similar effect. The apparent synchronism of these vegetation changes makes the argument of lake isolation from river floods, proposed here to explain the environmental change, even more appealing.

\section{THE CHARCOAL RECORD AND HUMAN IMPACTS}

The quantity of charcoal particles present in the sediments from Lake Márcio, measured here as charcoal area $\left(\mathrm{mm}^{2}\right)$ per volume of sediment $\left(\mathrm{cm}^{3}\right)$, was used as proxy for past fire frequency. Fires were recorded since 6900 cal. yrs BP, but very sporadically and at insignificant levels. However, they became much more frequent after 4590 cal. yr BP. As fire is most unlikely to have occurred in the mesic forests present around the sites at c. $7000 \mathrm{BP}$, the most probable cause of fire is human activity. Hence, these charcoal records may provide evidence of human impacts in the area since c. $6900 \mathrm{cal}$. yr BP.
As the dramatic increase of fire frequency is coincident with the vegetation change, it is possible that human impacts played an important role in the establishment of savannas in the region. Indeed, a testable hypothesis is that as the lake isolation reduced flooding in these systems, they became more suitable for human habitation. As people moved onto this landscape they introduced regular fire, thereby contributing to the expansion of the savannas.

\section{CONCLUSIONS}

The Holocene fossil pollen and charcoal records from Lake Márcio revealed a change from allochthonous to autochthonous sedimentation that was initiated by a reduction in river flooding. As the lake was dependent on seasonal flooding to maintain its hydrological balance, the reduced inputs resulted in a sedimentary hiatus lasting c. 550 years (5300 cal. yr BP to 4750 cal. yr BP).

The return of local wet conditions did not bring about a return to pre-drought conditions as a combination of factors, reduced river flooding, human occupation and fires, may all have played a role in deflecting the system onto a new path.

From these data it appears probable that the modern mosaic of savanna and mesic forest found around the lake formed by $4700 \mathrm{cal}$. yr BP, correlating closely with the estimated age of savanna mosaic formation in the lower Tapajós drainage (Irion et al. 2006). Despite resumption of wet conditions, the flooding of the system was never reestablished, consistent with the long-term change in hydrology induced by falling sea-levels in the late Holocene.

\section{ACKNOWLEDGMENTS}

Many thanks are due to several people from Brazil and the institutions they represent: Dr. Paulo de Oliveira (Universidade Guarulhos), Dr. Odete F. da Silveira, Instituto de Pesquisas Científicas e Tecnológicas do Estado do Amapá (IEPA), Marco Antonio Chagas and Odécio, Secretaria do Meio Ambiente do Estado do Amapá (SEMA-AP), MS. Ronaldo L. Justo. Financial support: Conselho Nacional de Desenvolvimento Científico e Tecnológico (CNPq) (200065/99-8) and National Science Foundation - Division of Environmental Biology (NSF/DEB-9732951). 


\section{RESUMO}

O objetivo deste estudo foi investigar a influência do clima e atividades antrópicas em ecótonos de savanas da Amazônia Brasileira. Os registros palinológicos e de microcarvões do Lago Márcio (Amapá) foram utilizados a fim de fornecer a história paleoecológica desta região durante o Holoceno. Foi utilizada a técnica de DCA (Análise de Correspondência Destendenciada) para demonstrar os padrões de distribuição de amostras ao longo do testemunho. O registro palinológico evidenciou mudança na vegetação, passando de floresta com elementos brejosos para savana inundada há cerca de 5000 anos AP. A análise de microcarvões revelou um aumento na acumulação de partículas paralelo ao estabelecimento de savanas, indicando alta freqüência de queimadas e do impacto humano próximo ao lago. A ocorrência de um hiato sedimentar de 550 anos sugere que o lago dependia das enchentes sazonais do rio Amazonas, e que se tornou abruptamente isolado. Quando a deposição de sedimentos reiniciou no lago, o ambiente estava mudado. Uma combinação de fatores, tais como redução na freqüência de cheias fluviais, paleo-incêndios, e ocupação humana deve ter tido um tremendo impacto no ambiente. Como não foram observadas outras mudanças importantes na vegetação, após 4700 anos AP, é plausível supor que o mosaico da vegetação atual formou-se naquele período.

Palavras-chave: registro palinológico, paleoqueimadas, Amazônia, savanas, mudança climática, paleoecologia.

\section{REFERENCES}

Behling H. 1996. First report on new evidence for the occurrence of Podocarpus and possible human presence at the mouth of the Amazon during the late-glacial. Veg Hist Archaeobot 5: 241-246.

BeHLing H AND Costa ML. 2001. Holocene vegetational and coastal environmental changes from the Lago Crispim record in northeastern Pará State, eastern Amazonia. Rev Palaeo Pal 114: 145-155

Behling H And Hooghiemstra H. 1998. Late Quaternary paleoecology and paleoclimatology from pollen records of the savannas of the Llanos Orientales in Colombia. Palaeo Palaeo Palaeo 139: 251-267.

Behling H AND Hooghiemstra H. 1999. Environmental history of the Colombian savannas of the Llanos Orientales since the Last Glacial Maximum from lake records El Pinal and Carimagua. J Paleolim 21: 461-476.

Berrio JC, Hooghiemstra H, Behling H, Botero P AND VAN DER BORG K. 2002. Late Quaternary savanna history of the Colombian Llanos Orientales from Lagunas Chenevo and Mozambique: a transect synthesis. The Holocene 12: 35-48.

Bush MB, Miller MC, de Oliveira PE and ColinVAUX PA. 2000. Two histories of environmental change and human disturbance in eastern lowland Amazonia. The Holocene 10: 543-554.

CLARK JS. 1988. Particle motion and the theory of charcoal analysis: source area, transport, deposition, and sampling. Quat Res 30: 67-80.

Clark JS AND PAtterson WAI. 1997. Background and local charcoal in sediments: Scales of fire evidence in the Paleorecord. Sediment Records of Biomass Burning and Global Change. NATO ASI Series. Series 1: Global Environmental Change vol. 51. J.S. Clark, H. Cachier, J.G. Goldammer and B. Stocks. Berlin, Springer, p. 2348.

Clark JS, Royall PD and Chumbley C. 1996. The role of fire during climate change in an eastern deciduous forest at Devil's Bathtub, New York. Ecology 77: 21482166.

Cochrane MA And Schulze MD. 1999. Fire as a recurrent event in tropical forests of the eastern Amazon: effects on forest structure, biomass, and species composition. Biotropica 31: 2-16.

Colinvaux PA, de Oliveira PE and Moreno Je. 1999. Amazon Pollen Manual and Atlas. New York, Harwood Academic Press.

ERICKSON CL. 2000. An artificial landscape-scale fishery in the Bolivian Amazon. Nature 408(9): 190-193.

ERICKSON CL. 2001. Pre-Columbian roads of the Amazon. Expedition 43(2): 21-30.

FAegri K And IVERSEN J. 1989. Textbook of Pollen Analysis, $4^{\text {th }}$ ed., FAegri K, KALAND PE, KRZYWINSKi K (Eds), J Wiley \& Sons, New York, 328 p.

GRIMM E. 1992. TILIA Software, Version 1.12, Illinois State University.

Heckenberger MJ, Kuikuru A, Kuikuru UT, RusSell JC, Schmidt M, Fausto C and Franchetto B. 2003. Amazonia 1492: pristine forest or cultural parkland? Science 301: 1710-1714.

Hill MO and GaUCh HG. 1980. Detrended correspondence analysis: an improved ordination technique. Vegetatio 42: 47-58.

Hooghiemstra H. 1984. Vegetational and climatic history of the high plain of Bogota, Colombia: A continuous record of the last 3.5 million Years. Vaduz, Gantner Verlag. 
IBGE. 2002. Mapa de Clima do Brasil. Rio de Janeiro, IBGE. Irion G, Bush MB, Nunes de Mello JA, Stüben D, Neumann T, Müller G, Moraes de JO and Junk JW. 2006. A multiproxy palaeoecological record of Holocene lake sediments from the Rio Tapajós, eastern Amazonia. Palaeo Palaeo Palaeo 240: 523-536.

JugGins S. 2003. C2 User guide. Software for ecological and palaeoecological data analysis and visualisation. Newcastle upon Tyne, University of Newcastle.

Kennedy LM And Horn SP. 1997. Prehistoric maize cultivation at the La Selva Biological Station. Biotropica 29: 368-370.

ListopAD C. 2001. Vegetational changes, fire history and human impact during the last 6000 years: a paleoecological study of the Madre de Dios Province, Lowland Peru. Department of Biological Sciences. Melbourne, Florida Institute of Technology, $190 \mathrm{p}$.

Marchant R ET AL. 2002. Distribution and ecology of parent taxa of pollen lodged within the Latin American Pollen Database. Rev Palaeo Pal 121: 1-75.

Mayle FE, Burbridge R And Killeen TJ. 2000. Millennial-scale dynamics of southern Amazonian rain forests. Science 290: 2291-2294.

McCune B ANd Grace JB. 2002. Analysis of Ecological Communities. Gleneden Beach, Oregon, MJM.

MCCune B And MefFord MJ. 1999. PC-ORD. Multivariate Analysis of Ecological Data. Gleneden Beach, Oregon, MjM Software.

Meggers BJ. 2003. Revisiting Amazonia circa 1492. Science 301: 2067.

MIRANDA IS AND ABSY ML. 1997. A flora fanerogâmica das savanas de Roraima. Homem, Ambiente e Ecologia no Estado de Roraima. BARbosa RI, FERreirA EJG, CASTELlón EG (Eds), INPA, Manaus, AM, Brasil, p. 445-462.

Patterson WA, Edwards KJ And Maguire DJ. 1987. Microscopic charcoal as a fossil indicator of fire. Quat Sci Rev 6: 3-23.

Roosevelt aC, Housley Ra, imazio da Silveira M, MARANCA S AND JOHNSON R. 1991. Eighth millennium pottery from a prehistoric shell midden in the Brazilian Amazon. Science 254: 1621-1624.
Roosevelt AC Et AL. 1996. Paleoindian cave dwellers in the Amazon: the peopling of the Americas. Science 272: 373-384.

Roubik DW And Moreno E. 1991. Pollen and Spores of Barro Colorado Island. Monographs in Systematic Botany, v. 36, Missouri Botanical Garden.

Salgado-Labouriau ML. 1973. Contribuição à Palinologia dos Cerrados. Acad Bras Cienc (Eds), Rio de Janeiro, RJ, Brasil, $291 \mathrm{p}$

SAlgado-LABOURIAU ML. 1997. Late Quaternary paleoclimate in the savannas of South America. J Quat Sci 12: 371-379.

SILVA ELS. 1997. A vegetação de Roraima. Homem, Ambiente e Ecologia no Estado de Roraima. BARBOSA RI, Ferreira EJG and Castellón EG (Eds), INPA, Manaus, AM, Brasil, p. 400-415.

STOCKMARR J. 1971. Tablets with spores used in absolute pollen analysis. Pollen Spores 13: 615-621.

Stuiver M AND Reimer PJ. 1993. Extended ${ }^{14} \mathrm{C}$ database and revised CALIB radiocarbon calibration program. Radiocarbon 35: 215-230.

Thomaz DO, Neto SVC And Tostes LCL. 2004. Inventário florístico das ressacas das bacias do Igarapé da Fortaleza e do rio Curiaú. Diagnóstico de ressacas do Estado do Amapá: Bacias do Igarapé da Fortaleza e do rio Curiaú. TAKYYAMA LR AND SILVA AQ (Eds), JM Editora Gráfica, Macapá, AP, Brasil, p. 13-32.

Tissot C, DJuwansah MR and Marius C. 1987. Evolution de la mangrove en Guyane au cours de l'Holocène étude palynologique. $10^{\text {th }}$ Symposium APLF, Bordeaux, Institut Français Pondicherry.

VAN DER HAMmen T. 1963. A palynological study on the Quaternary of British Guiana. Leidse Geol Mede 29: 125-180.

Wijmstra TA. 1971. The Palynology of the Guiana coastal basin. Amsterdam, University of Amsterdam, 62 p. 